\title{
Kamp om Turkmenistans gas efter Turkmenbasji
} Vibeke Sperling

\author{
Rusland har sikret sig fuld kontrol med gas fra \\ Turkmenistan, hvor den ny præsident hidtil har \\ skuffet vestlige håb om, at vinterens magtskifte vil- \\ le åbne for gasleverancer uden om Rusland.
}

Præsidentvalget i Turkmenistan i februar efter diktatoren Saparmurat Nijasovs død den 21. december var afgjort på forhånd til fordel for Gurbangulij Berdymuhammedov. Almindelige turkmenere har endnu ikke vist tegn til at bruge magtskiftet til at kræve ændringer i et af verdens mest diktatoriske lande. Det vil formentlig også tage sin tid, da Nijasov har holdt borgerne i stramt greb i over tyve år og hans undertrykkelsesapparat forekommer intakt.

Nijasov blev leder af den turkmenske afdeling af Sovjetunionens Kommunistpartiet i 1985. I 1992, året efter Sovjetunionens sammenbrud, var han den eneste kandidat til det dengang selvstændige lands præsidentvalg. Han smadrede en gryende opposition og trængte udfordrere i eksil, tog fuld kontrol med medierne og slog ned på alt kritisk, som rørte sig. I stedet for kommunismen skabte han en særlig nationalistisk ideologi, centreret om sig selv som han udråbte til Turkmenbasji, 'alle turkmeneres fader'.

Han skabte en personkult, der ikke stod tilbage for Stalinkulten, men havde flere latterlige træk som de mange forgyldte monumenter af kultfiguren og forgyldte paladser, som han brugte landets energirigdomme på, mens over halvdelen af befolkning blev kastet under fattigdomsgrænsen.

Turkmenistan har betragtelige valutaindtægter fra dets to vigtigste ressourcer: gas og bomuld. Landet råder over en femtedel af verdens kendte gasreserver, men økonomien lider under den ideologiske styring af alt, som rører sig. Og det forhold at Nijasov konstant fyrede ministre, angiveligt for inkompetence og kor- 
ruption, forhindrede kontinuitet $\mathrm{i}$ den økonomiske ledelse.

Turkmenistans store energirigdomme har internationaliseret magtskiftet, selv om Rusland øjensynlig har kunnet blande sig direkte.

Efter Nijasovs død tog det kun få timer for Gurbangulij Berdymuhammedov at stå frem som elitens udvalgte efterfølger. Det blev set som en særlig kvalitet hos ham, at han har holdt sig i toppen af magtapparatet. Han blev sundhedsminister i 1997 og viceministerpræsident fra 2001 i en regering, hvor de færreste overlevede ret mange måneder. Som sundhedsminister havde han ansvaret for Turkmenbasjis massefyring af læger og sygeplejersker og for, at værnepligtige blev sat ind i deres sted.

Berdymuhammedov vandt 12 . februar en overvældende sovjetlignende sejr i et valgsystem, der udelukker fair valg. Han fik knap 90 procent af stemmerne med en officiel valgdeltagelse på 99 procent. Lederen af valgkommissionen, Murat Garryjev, støttede ham åbent og de fem modkandidater, som delte krummerne, kom alle fra det regerende parti.

\section{Løfter om reformer}

Den nye leder har lovet reformer, men samtidig at fastholde Nijasovs kurs. Hans mænd mener øjensynlig, at der ikke skal rokkes for meget ved båden, for de henter deres legitimi- tet i systemet, som Nijasov skabte. Men meget tyder på, at landets diktatoriske stabilitet eller rettere stilstand nu er ved at blive fortid. "I et land med så kort en historie som stat, er der centrifugale kræfter især i form af regionale interessegrupper - der kan udfordre Nijasovs efterfølgere", hedder det i en analyse om magtskiftet fra International

\section{Crisis Group.}

Indsættelsen af den nye præsident i midten af februar blev en parade af internationale aktører i kappestriden om adgangen til turkmensk gas. Med højtstående delegationer viste de fleste af aktørerne, Rusland, USA, Kina, Iran, Tyrkiet, Ukraine og Aserbajdsjan, deres særlige interesse. De fleste af dem viste også viljen til at vende det blinde øje til undertrykkelsen for gassens skyld.

Gæsterne vidste selvfølgelig, at OSCE havde karakteriseret præsidentvalget som en farce, men de havde vendt det døve øre til bønner fra turkmenske oppositionelle, som Nijasov drev i eksil, om at lægge pres på regimet i Asjkhabad for at lade dem vende tilbage og deltage i valget. "Der er simpelthen for meget på spil til at tage sig af forstyrrende elementer, især dem, som kan skade chancerne for gevinst i den forestående kappestrid", hed det i en kommentar på Eurasia.net.

Ukraines præsident, Viktor Jusjtjenko, der kom til magten efter annullering af et præsidentvalg, som var mindre svindelagtigt end Turk- 
menistans, reagerede hurtigt på en protest fra Asjkhabad. Han krævede fyring af transportminister Nikolaj Rudovskij, der havde tilladt sig at invitere turkmenske oppositionelle til Kijev efter Nijasovs død i december. Som tak fik Jusjtjenko en plads tæt på den nye turkmenske præsident ved indsættelsesceremonien.

Ukraine har forgæves forsøgt at få bilaterale aftaler i hus med Nijasov om gasleverancer for at mindske Kijevs afhængighed af russisk gas. Ukraine får turkmensk gas, men via det russiske gasmonopol Gasprom. $\mathrm{Nu}$ øjner Ukraine en ny chance for direkte turkmenske leverancer.

Aserbajdsjans præsident, Ilham Alijev, var der også og hyldede sit lands 'varme relationer' til Turkmenistan, selv om de i bedste fald har været kølige. Siden Sovjetunionens sammenbrud har relationerne for det meste været højspændte, primært på grund af konflikter om den territorielle deling af det Kaspiske Havs undergrund, der er rig på olie og gas. Nijasov afbrød de diplomatiske forbindelser med Aserbajdsjan i 2001, men efter hans død har Baku startet en veritabel charmeoffensiv. Den gælder især den såkaldte Transkaspiske Gasledning (TCP), et regionalt projekt, der efter planerne skal bringe 32 milliarder kubikmeter gas til Europa fra den kaspiske region - uden om Rusland.

På baggrund af EU's stigende tvivl om Ruslands pålidelighed som leverandør, satser Aserbajdsjan på at bli- ve energibåndet mellem Centralasien og Europa. Det tilkendegav den aserbajdsjanske præsident, Ilham Alijev, åbent på World Economic Forum i Davos i slutningen af januar. Og repræsentanter for Aserbajdsjans statslige olieselskab sagde ved samme lejlighed, at det nu er en topprioritet for aserbajdsjansk diplomati at få Turkmenistan med i TCP.

Kommentatorer fremhæver, at turkmenske ledere spiller på modsætningerne blandt bejlerne. Der er mange eksempler på, at Asjkhabad favoriserer den ene og så den anden part. Som under Nijasov anses det for at være en bevidst taktik for at holde krav om demokratisering fra dørene.

\section{USA's missilskjold}

En anden aktuel strid spiller ind, nemlig om de amerikanske missilskjoldsplaner, der føjer sig til den skærpede øst-vest strid i Sydkaukasus og Centralasien. Den 1. marts hed det i en erklæring fra den amerikanske general Henry Obering, leder af Missile Defense Agency, at en missilforsvarsenhed i Kaukasus kan være "nyttig' for det projekt.

Analytikere mener, at Aserbajdsjan og Georgien er de mest sandsynlige placeringer. Regeringerne $\mathrm{i}$ de to lande har afvist, at der skal have foregået drøftelser herom med USA, men Oberings udtalelser kastede yderligere brænde på bålet imod missislskjoldet i Moskva, hvor- 
fra det lød, at det vil bringe de pågældende lande i fare for missilangreb fra Iran og dermed også true Rusland.

I Ruslands dybe konflikter med Georgien, der har betydet, at det fattige sydkaukasiske land nu betaler lige så meget som EU-lande for russisk gas, har Moskva forgæves forsøgt at alliere sig med Aserbajdsjan imod Georgien. Striden om missilskjoldet har imidlertid fået Rusland til at søge at forbedre det spændte forhold til de to lande.

\section{EU, USA og TCP}

Både EU og USA er varme tilhængere af TCP-projektet. Ifølge det aserbajdsjanske nyhedsbureau Turans Energi Bulletin opmuntrer begge parter Aserbajdsjan i frieriet til Turkmenistan. EU ser TCP som en vej til andre forsyninger end fra Rusland. Ifølge Turan har Bruxelles siden Nijasovs død allokeret 1,7 millioner euro til en undersøgelse af Turkmenistans deltagelse i TCP som et europæisk-aserbajdsjansk konsortium er i færd med at udarbejde.

Den aserbajdsjanske analytiker Rovshan Ismajilov skriver til Eurasia Net: "Om der nogensinde vil komme et svar (på Aserbajdsjans opfordring til Turkmenistan til samarbejde om TCP) og hvad det i givet bliver, kan der kun gisnes om, ifølge iagttagere i Baku. På baggrund af den eksisterende mangel på viden om Berdymukhamedovs politiske og økono- miske dagsorden er forudsigelser om relationerne til Turkmenistan lig med at spå om fremtiden i kassegrums".

Der er indlysende fordele for Turkmenistan at hente i TCP-projektet, men det og andre lignende alternative gasledninger kan svække Gasprom alvorligt i Europa. Og Moskvas modstand er den største forhindring for TCP. Nijasovs død skabte nervøsitet i Gasprom og i Kreml for den 25-årige kontrakt, som Nijasov og hans russiske kollega Putin underskrev i 2003, som giver Gasprom noget nær hals- og håndsret over turkmensk gas. Nijasovs død skabte forhåbninger om, at en ny leder kunne overbevises om det profitable i gasledninger over Det Kaspiske Hav, der gør det muligt at eksportere turkmensk gas gennem Aserbajdsjan, Georgien og Tyrkiet.

Georgiens præsident Mikhail Saakasjvili og Tyrkiets ministerpræsident Recep Tayyip Erdögan var også til Berdymukhamedovs præsidentindsættelse i februar, hidkaldt af gasinteresser vendt imod det russiske monopol.

Men Rusland ser ud til at have fået alt, hvad det kunne ønske i spillet om gassen.Ruslands ministerpræsident Mikhail Fradkov fik et løfte fra den nye præsident om, at Rusland vil beholde eksklusive rettigheder til at eksportere turkmensk gas i det mindste til 2028.

Nijasov havde lovet at forsyne Kina med 30 milliarder kubikmeter 
gas om året fra 2009, men nåede ikke at underskrive en endelig aftale, så "Gasprom forbliver eneimportør af turkmensk gas”, skrev den russiske erhvervsavis Kommersant. Ifølge en tidligere aftale, som blev bekræftet under Fradkovs besøg, vil Turkmenistan sælge 60 milliarder kubikmeter gas til Rusland i år, 60-70 milliarder i 2008 og op til 80 milliarder kubikmeter hvert år frem til 2028. Turkmenistan må imidlertid fordoble sin gasproduktion for at leve op til den kontrakt. I 2005 importerede Gasprom kun 42 milliarder kubikmeter gas fra Turkmenistan, mindre end lovet, så der er næppe kapacitet i Turkmenistan til at indfri Nijasovs løfter til Kina.

Kreml er især begejstret for, at Kina således synes skudt ud på sidelinjen, ifølge Kommersant, der citerede en kilde i den russiske delegation for at sige: "Nijasov blev heldigvis ikke givet tid til at afslutte aftalen med Kina”.

\section{Rusland nedtrapper eksport}

For første gang i seks år vil Rusland nedtrappe sin gaseksport - med to procent i år - for at kunne levere mere gas til hjemmemarkedet. Den uindfriede interne efterspørgsel kombineret med Ruslands forpligtelser over for EU-lande betyder, at Gasprom bliver mere afhængigt af Kremls politiske relationer til centralasiatiske lande. Mens den russiske gas går til EU, videresælger Rus- land gas fra de centralasiatiske lande Turkmenistan, Usbekistan og Kasakhstan til SNG-lande.

De energirige centralasiatiske lande har alle i samarbejde med vestlige energikoncerner søgt at bryde Ruslands monopol på energieksporten fra regionen. Men sporene fra folkelige oprør i Georgien, Ukraine og det centralasiatiske Kirgisistan skræmmer. I takt med at præsidenternes liv i Usbekistan og Kasakhstan også nærmer sig udløbsdatoen, får eliterne stadig mere berøringsangst over for vestlige lande, der kan tænkes at presse dem til demokratiseringer. Det er der ikke fare for fra Rusland. Med løfterne fra Turkmenistans nye præsident synes Rusland stærkere end nogensinde i regionens energispil.

Om Berdymuhammedov kan tænkes at ændre landets eksportstrategi mener analytikere kun, at der kan gisnes om. Det samme synes at gælde for den indenrigspolitiske udvikling. Blandt Gurbanguly Berdymuhammedovs valgløfter var reformer i et sundheds- og uddannelsessystem, som Nijasov kørte helt i sænk.

Berdymuhammedov har også lovet mere adgang til verden udenfor bl.a. gennem Internet. To internetcafeer er åbnet i Asjkhabad som resultat af hans valgløfter, men adgangen er censureret, cafeerne bevogtet af soldater og det koster en mindre formue at komme på nettet ad denne officielle vej. Men selv om Berdymuhammedov lover at følge forgæn- 
gerens linje, kan hans løfter ses som en vis indrømmelse af, at der var noget helt galt med Turkmenbasjis kurs.

International Crisis Group skriver: "I det omfang de (nye ledere) er i stand til at styre processen og ressourcerne fra salg af gas og bomuld til udlandet, kan de bruge pengene til at forbedre velfærd, sundhed og uddannelse, mens de vil forhindre forsøg på at skabe et mere pluralistisk politisk system. Det lettes af deres magt til at blokere adgang til landet for højtråbende modstandere i eksil og til fortsat at undertrykke alle tegn på kritik hjemme”.

En ændring af Nijasovs socialpolitik til gavn for den ludfattige befolkning kan sikre den nye præsident folkelig popularitet. Ifølge iagttagere i landet er turkmenerne stadig så underkuede, at de vil stille sig tilfredse med selv små ændringer til det bedre. Og der eksisterer ingen uafhængige politiske partier eller sociale organisationer til at organisere protester. Det er derimod som nævnt tænkeligt, at regionale magthavere vil forsøge at udfordre eliten i hovedstaden.

I de centralasiatiske tidligere sovjetrepublikker har lederne minus i Kirgisistan og nu Turkmenistan været ved magten siden sovjettiden.

\section{Som efter Stalins død}

Mens ledere er trængt fra magten i andre tidligere sovjetrepublikker savnes erfaringer med, hvad der sker efter en statsleders død som i Turkmenistan. Men et fortilfælde er der i Aserbajdsjan, hvor Hejdar Alijev blev efterfulgt af sønnen Ilham i 2003. Men det skete efter en lang sygdomsperiode for faderen, hvor magtkampe blev løst inden for den herskende elite.

Turkmenistan er i stedet blevet sammenlignet med begivenhederne efter Stalins død i 1953, hvor arvtagerne ændrede diktatorens enemagt til kollektiv magtudøvelse "og rullede nogle af tyranniets værste yderligheder tilbage, mens de blev ved med at hylde det system, der konsoliderede deres legitimitet".

Det er begrænset, hvad der er sluppet ud fra magtens korridorer, men Berdymuhammedov synes at have den tidligere præsidents regering bag sig. Nogle analytikere mener, at han ikke er andet end en overgangsfigur for de såkaldte siloviki, sikkerhedsstyrkernes mænd. International Crisis Group påpeger, at Nijasovs arvtagere må afklare en række modsætninger:

- Der tales om en vis liberalisering, men de nye ledere kan ikke hurtigt tage afstand fra Nijasovs arv, da den er deres kilde til legitimitet.

- Uden udsigt til demokratiske reformer vil det hierarkiske system blive videreført, men spørgsmålet er, om det kan fungere uden den almægtige enehersker. Som den turkmenske analytiker Shohrat Kadyrov udtrykker det, så har de politikere 
og oligarker, der udgør eliten, "ikke brug for en ny Turkmenbasji”.

- Administrationen tvinges til at anerkende regionale krav om indflydelse, men vil få svært ved at løsrive sig fra den nuværende afhængighed af blot en gruppe, Tehe-stammen fra Ahal-regionen.

Murat Esenov, turkmen i eksil i Sverige og chefredaktør for bladet Central Asia and Caucasus, siger i et interview til IWPR (International War and Peace Reporting), at magtmekanismerne har overlevet deres skaber: "Systemet fungerede i realiteten ret fint uden Nijasov. Efter hans død forventede mange kaos eller magttomrum, men intet af det skete. Men andre ord var Nijasov i stand til at skabe en magtstruktur, der forbliver mere eller mindre funktionsdygtig, selv efter at han er væk". Kun de nye magthavere kan ændre systemet, ingen kan tvinge dem til det, mener Esenov.

Vjatjeslav Mamedov, leder af Den Demokratiske Borgerunion, en turkmensk eksilgruppe, mener, at "systemet har bestået den værste prøve efter Nijasovs død".

Arkadij Dubnov, Turkmenistanekspert ved Moskva-avisen Vremja Novostej, mener derimod, at Nijasovsystemet er brudt sammen med hans død. "Det fungerede, mens han var øverst på pyramiden. Uden ham kan det ikke længere fungere. Det vil kræve opkomsten af en ny leder, der styrer landet gennem den frygt, der gennemsyrer alle dele af samfundet.
Jeg tror ikke, at vi vil se en gentagelse af den slags personkult", siger Dubnov.

Michael Denison ved Leeds University siger, at det vil tage tid for en ny ledelse at lægge afstand til Nijasovs stadig altoverskyggende tilstedeværelse. "Alt afhænger af, om den nye ledelse ønsker at videreføre Nijasovs kult eller ønsker gradvist at afvikle den. Det tog tre år, før afviklingen af Stalinkulten begyndte. Jeg venter ikke, at de straks vil påbegynde det, men gradvist, når hans minde vil mindskes i folks erindring og de begynder at se fremad".

Regionale og modstridende interesser ventes at spille en stadig større rolle, men det monolitiske sikkerhedssystem menes længe at kunne holde ændringer fra døren. Nogle analytikere ser Berdymuhammedov som en ubetydelig figur, skabt af sikkerhedssystemets top. Andre mener, at han nyder respekt som den store overlever ved Nijasovs hof.

\section{Den usædvanlige lyd}

Transition Online (TOL) skrev om præsidentvalget: "Den usædvanlige lyd, der kommer fra Turkmenistan, er almindelige menneskers stemme”. Ifølge TOL var den autoritære gennemførelse af præsidentvalget "et alvorligt anslag imod vestlige forventninger om ændringer i Turkmenistan, i hvert fald på mellemlangt sigt".

"Stemningen i landet efter Nija- 
sovs død er præget af tøvejr. Det er ikke som under tøvejret i 1960'erne, hvor folk gik på gaden med guitarer. Men nu er der mere en følelse af stille optimisme", sagde en vælger til TOL. En anden sagde, at valget forløb som altid, men han følte nye toner i medierne: "Det var interessant at læse aviserne, at læse almindelige menneskers kommentarer. Jeg kender mange af dem personligt, så det var reelt eksisterende mennesker, som skrev. Jeg har virkelig fornøjelse af at læse avisen Neutralnij Turkmenistan nu. Folk opfordrede kandidaterne til at sørge for reformer i landbruget, private virksomheder, uddannelse og pensioner. Det tilfredsstillende er, at folk har givet udtryk for konkrete bekymringer. Det skete aldrig tidligere".

En tredje vælger sagde: "Den ældre generation har helt mistet håb og har ingen tro på, at tingene kan ændres til det bedre. Nogle unge er mere optimistiske og ønsker at tro på fremskridt".

Observatører har med god grund betvivlet den officielle valgdeltagelse på 99 procent, men mange viste sig ivrige efter at stemme, alene fordi noget syntes i bevægelse. Og mange vælgere sagde til journalister, at de så spidskandidaten som det bedste bud på en leder, der kan garantere en fredelig politisk reform. "Jeg kunne virkelig godt lide, at da Nijasov døde, spildte Berdymukhammedov ikke et øjeblik. Regeringsudøvelsen fortsatte uden afbrydelse.
Det kunne folk lide og tog det i betragtning, da de stemte".

\section{Tyrkiet ind på banen}

Blandt de udenlandske spillere synes Tyrkiet at have placeret sig godt over for den nye ledelse i Asjkhabad. "Der vil blive hård konkurrence og interessekonflikt imellem Vesten og Tyrkiet", siger Sinan Ogan, leder af Tyrkisk Center for Internationale Relationer, til Moscow Times. Han understreger, at tyrkerne og turkmenerne ud over etniske bånd også deler strategiske interesser.

Moscow Times påpeger, at det isolerede Turkmenistan desperat har forsøgt at undgå afhængighed af større udenlandske magter. "Tyrkiet kan give dem den mulighed. I et af verdens mest dynamiske opstigende markeder siger lederne, at landet vil bruge sit gode forhold til Vesten til at blive den energikorridor, der forbinder Centralasien og Kaukasus med Europa. Men i takt med at Tyrkiets ønske om EU-medlemskab svækkes, har de moderate islamister ved magten i Ankara ingen problemer med at skue imod øst i stedet for mod vest". Tidligere talsmand for det tyrkiske udenrigsministerium, Murat Ozcelik, siger til bladet: "Vi føler et vist ansvar for dem. De har visse problemer med blandt andet frihedsrettigheder, hvor vi kan hjælpe dem". Og sammenlignet med Turkmenistan fremstår Tyrkiet som en liberal bastion med særlige 
forudsætninger for at påvirke den turkmenske regering.

Turkmenerne har tidligere skuet imod Tyrkiet. Nijasov skrev i sin bog Ruhnama, som stort set styrede uddannelsessystemet: "Den dag, hvor jeg erklærede Turkmenistan selvstændigt, erklærede jeg, at Turkmenistan og Tyrkiet er to stater, men en nation. Det er vi turkmener stolte af og forventer det samme fra vore tyrkiske brødre". Og da Nijasov kaldte sig selv Turkmenbasji tog han bevidst grundlæggeren af det moderne Tyrkiet som sin model, Kemal Atatürk. Atatürk betyder 'alle tyrkeres far' som Turkmenbasji 'alle turkmeneres far'.

Nijasovs stigende paranoia isolerede også Turkmenistan fra Tyrkiet, men Berdymukhammedov viede den tyrkiske ministerpræsident Erdögan særlig stor opmærksomhed under dennes besøg. Tyrkiske virksomheder er massivt til stede i Turkmenistan, landets største indkøbscentre er proppet med tyrkiske varer og turkmenske unge orienterer sig i stigende tal imod Tyrkiet.

"Det var naturligt for Erdogan at tage til Turkmenistan. Det er en allieret af største betydning på grund af dets rige ressourcer", siger analytikeren Ogan til den russiske avis.

\section{EU's falske forhåbninger}

Men EU's håb om turkmensk gas til at mildne afhængigheden af russisk har magtskiftet ikke givet næring. Uden dybtgående reformer og enorme udenlandske investeringer synes Turkmenistan end ikke i stand til at indfri forpligtelserne over for Rusland. "Der eksisterer den alvorlige misopfattelse i Europa, at Turkmenistan specielt og Centralasien generelt på en eller anden måde kan optræde som energifrelser for Europa”, sagde Andrew Stroehlein, mediedirektør for International Crisis Group, da han offentliggjorde overnævnte rapport om Turkmenistan i februar. "Sådanne forhåbninger er en urealistisk overvurdering af potentialerne og en grov undervurdering af forhindringerne", sagde han.

Som det er nu, kan Turkmenistan kun eksportere gennem Central Asia-Center gasledningen igennem Usbekistan, Kasakhstan og Rusland. Gasproms kontrol med den turkmenske gas synes styrket af magtskiftet i Usbekistan, og EU gør klogest i at indse, at hårdt pres for politiske og økonomiske reformer er den eneste vej til at ændre det. Men Turkmenbasjis efterfølger synes mere opsat på at bevare regimet end at åbne for reformer, som vil skylle det væk.

Vibeke Sperling er journalist ved Politiken og forfatter. 